\title{
article CROSSINGS Of TIME AND LOOK IN THE JOURNALISTIC IMAGE OF PRECARIOUS LIVES IN "CRACOLÂNDIA" (sp)
}

\author{
LUIS MAURO SÁ MARTINO \\ Faculdade Cásper Líbero, São Paulo - SP - Brazil \\ ORCID: 0000-0002-5099-1741 \\ VITÓRIA PRIETO AMÁ \\ Faculdade Cásper Líbero, São Paulo - SP - Brazil \\ ORCID: 0000-0002-5673-6223 \\ ÂNGELA CRISTINA SALGUEIRO MARQUES \\ Universidade Federal de Minas Gerais, Belo Horizonte - MG - Brazil \\ ORCID: 0000-0002-2253-0374
}

DOI: 10.25200/BJR.v17n2.2021.1367

Received in: November $27^{3}, 2020$

Desk Reviewed: December $8^{\text {th }}, 2020$

Desk Review Editor: Cláudia Lago

Revised on: February $8^{\text {th }}, 2021$

Approved on: March $31^{\text {st }}, 2021$

\begin{abstract}
This article outlines the media representation of the "precarious life", as Butler $(2004,2014,2016)$ defines it, as a form of life deprived of its fundamental rights. The focus is on the analysis of photojournalistic images of two police operations (2017 and 2018) in "cracolândia", a region in São Paulo's downtown. From a corpus of 109 images published by the news portals UOL, G1, and R7, we selected eight photographs for a closer analysis of elements that tension the biopolitics of control (Foucault, 1980), impersonality, and disregard for precarious lives, with attempts at survival (DidiHuberman, 2017) and resistance from vulnerabilities. We identified the presence of three main dimensions of representation: (1) although there is six months between the events, media representation follows a similar pattern of representation; (2) the pictures focus on vulnerable, dispossessed life, but also show the defiant and resistance power of faces and gestures; (3) the individual images of suffering, loss, and grievance are counterpointed by hints of rage and reaction. These elements are analyzed in the light of the reflections that intertwine photojournalism with the ethics of responsibility (Mondzain, 2009; Caron, 2007), which indicates possibilities of approaching and meeting otherness.
\end{abstract}

Keywords: Media. Otherness. Image politics. Framing. Photojournalism. 


\section{ATRAVESSAMENTOS DO TEMPO E DO OLHAR NA IMAGEM JORNALÍSTICA DE VIDAS PRECÁRIAS DA “CRACOLÂNDIA” (SP)}

RESUMO - Este artigo delineia alguns aspectos da representação, pela mídia, do que Butler $(2004,2014,2016)$ define como "vida precária", forma de existência desprovida de direitos e condições básicas. O foco é a análise de imagens fotojornalísticas de duas operações policiais (2017 e 2018) na "cracolândia", centro de São Paulo. A partir de um corpus de 109 imagens publicadas pelos portais de notícias UOL, G1 e R7, selecionamos oito fotografias para uma análise mais detida de elementos que tensionam a biopolítica do controle (Foucault, 1980), da impessoalidade e da desconsideração das vidas precárias, com as tentativas de sobrevivência (DidiHuberman, 2017) e resistência a partir das vulnerabilidades. Identificamos a presença de três dimensões principais de representação: (1) há padrões semelhantes de representação, apesar dos eventos estarem separados por seis meses; (2) a cobertura foca na vulnerabilidade dos retratados, mas também há sequências de resistência, sobretudo nas imagens da face e nas gestualidades; (3) imagens individuais de sofrimento, perda e luto encontram um contraponto em expressões de raiva e reação. Esses elementos são analisados à luz das reflexões que entrelaçam o fotojornalismo à ética da responsabilidade (Mondzain, 2009; Caron, 2007), pensando as possibilidades de aproximação e encontro com a alteridade.

Palavras-chave: Mídia. Alteridade. Política da Imagem. Enquadramento. Fotojornalismo.

\section{INTERSECCIONES DE TIEMPO Y MIRADA A LA IMAGEN PERIODÍSTICA DE VIDAS PRECARIAS EN “CRACOLÂNDIA” (SP)}

RESUMEN - Este artículo delinea algunos aspectos de la representación, por los medios, de lo que Butler $(2004,2014,2016)$ define como "vida precaria", existencia sin derechos y condiciones básicas. El foco es cobertura periodística de dos operaciones policiales (2017 y 2018) en la "cracolândia", región central de la ciudad de São Paulo. La atención se centra en el análisis de imágenes de fotoperiodismo de dos operativos policiales en "cracolândia", en el centro de São Paulo. De un corpus de 109 imágenes publicadas por los portales de noticias UOL, G1 y R7, seleccionamos ocho fotografías para un análisis más detallado de elementos que tensan la biopolítica del control (Foucault, 1980), la impersonalidad y el desprecio por la vida precaria, con intentos de supervivencia (Didi-Huberman, 2017) y resistencia a vulnerabilidades. Identificamos la presencia de tres dimensiones principales de representación: (1) hay similitudes de representación, aunque los eventos están sean distintos; (2) la cobertura se enfoca en la vulnerabilidad de los retratados, pero también hay secuencias de resistencia, sobre todo en las imágenes de la cara y en los gestos; (3) imágenes individuales de sufrimiento, pérdida y luto encuentran un contrapunto en expresiones de rabia y reacción. Estos elementos se analizan a la luz de las reflexiones que entrelazan el fotoperiodismo con la ética de la responsabilidad (Mondzain, 2009; Caron, 2007), pensando en las posibilidades de acercamiento y encuentro con la alteridad.

Palabras clave: Medios. Otredad. Política de la imagen. Encuadramiento. Fotoperiodismo. 


\section{Introduction}

Susan Sontag (2003), in her book Regarding the Pain of Others, puts into question a problem concerning the visuality of suffering: how is it possible to look at life without any dignity? How to look at the affronting image precisely because it portrays a situation of injury to what is considered, in modernity, fundamental rights of the human being? Given the interpellation of the other's gaze in a vulnerable, precarious, or desolate situation, what is the possibility of indifference? Furthermore, in an almost paradoxical way, what is the sense of attraction of the disturbing image? What does it remind, what does it represent?

For Sontag, the sense of the image of the other in suffering does not end within the image's scope itself. However, it spreads out in a network of references in which each scene finds resonance in others and shows, on a large scale, a common form that, in its rawness, causes an even stronger shock the more it seems to be fast in its dilution.

More than a decade later, resuming Sontag's reflections, Judith Butler (2016) questions not only the powers of representation of the image but also where the conditions of opposition are formed. The forms of representation of otherness are founded on these conditions, framed in different ways. In all of them, escaping the intended meaning from overflowing the representation itself tensioned with other social and political practices. The scenes representing precariousness of life, with the display of bodies far from the expected standards of contemporary "health" and "beauty", also show themselves as spaces of a challenge due to their presence within an environment from which, usually, they would be excluded.

The multivocality of elements in the image reinforces the vulnerable aspect without leaving aside a call to responsibility, establishing some reaction before the other. There is the expectation of sharing - at a distance - the experience of the other, reinforced by the feeling offered through the image of the bodies allowing to intuit the sensitive experience of otherness, the pathos governing it at some point. This is the condition, says Edith Stein $(2005,2015)$, for the movement of approximation before the gesture of sensitivity towards the one who appears before us.

In the contemporary, the representation of precariousness can be found in countless situations, confronting the exuberance of 
life forms and modes of existence considered desirable and correct. There is a sharp contrast to representations, in which a perfect form of existence finds its counterpoint in forms of life that are denied their affirmation as a human being. In this text, the theme of the precariousness of existence finds its focus in the context of media representation. It occurs mainly in the construction and elaboration of images about two particular events, official operations for evicting an area known as "cracolândia", in São Paulo downtown. Cracolândia, or "crack land", is a busy and active region of the city, occupied by a homeless population, mainly composed of drug addicts and traffickers, usually crack. The objective is to outline some of the forms of representation of precarious lives, in a sense defined by Butler $(2014,2016)$ as a form of existence without fundamental rights and conditions, based on the photojournalistic coverage of these two police operations.

The construction of the methodological research path encompassed the content analysis of reports published by UOL, $\mathrm{G} 1$, and R7 portals on the operation dates to evict cracolândia (respectively $05 / 21 / 2017$ and $11 / 28 / 18$ ) and in the next twenty days (05/22/17 to 06/11/17; and $11 / 29 / 18$ to $12 / 19 / 18)$. It is essential to mention that the R7 news portal is one of the largest Brazilian internet portals. It was created in 2009 and belongs to Record Group, an open commercial television network currently owned by neo-pentecostal bishop Edir Macedo. UOL is a Brazilian company with internet content, products, and services, belonging to the UOL PagSeguro Group. UOL news portal currently ranks third among the most visited websites in Brazil, behind Google and Facebook. G1 portal, which is part of Globo's journalistic content production network, updates its content 24 hours a day and currently ranks fifth among the most visited websites in Brazil.

From this collection of texts, 62 images were selected related to the dates of the operations and 47 images that portrayed the 20 days after these dates, totaling 109 images. Among them, we chose eight photographs we consider evidencing how photojournalism can contribute to building framings reiterating biopolitics of control and disregard for precarious lives (Foucault, 1980; Butler, 2004, 2015).

The choice of these portals as a source for capturing images is because they are currently some of the main spaces for the circulation of online journalistic information in Brazil. For this analysis, differences in the editorial line of the vehicles and the 
technical specificities, for example, of displaying in separate images or photo galleries, were not taken into account. More than exploring the technical or journalistic issue, the objective is to work with aspects of the photojournalistic representation of precarious life forms.

In our reflection, we highlight the framings that operate in visual images within the logic of photojournalism, pointing up values and principles that guide the moral evaluation of stigmatized behaviors and ways of life. Photojournalistic images contribute to ethical reflexivity (Buitoni, 2011 ; Sousa, 2004; Reis Filho, 2019), as they produce both vectors of humanization of the gaze (Barcelos, 2009; Caron, 2007; Zerwes, 2017), as well as sense pictures capable of corroborating the unequal distribution of vulnerability between different subjects and groups (Biondi \& Marques, 2015). According to Picado (2009), the relationship between ethics, esthetics, and politics in photojournalism becomes more concrete when we realize that most images reiterate hasty moral judgments and labels that make them invisible and do not contribute to the social recognition of people most exposed to vulnerability.

According to Reis Filho (2017, 2019), the image, especially the photojournalistic one, is fundamental in the creation of political imaginary that can reiterate or challenge the dominant and asymmetrical discourses organizing the world based on a separation between those who can speak and those who cannot, those who can be considered interlocutors and those who cannot. Images are also essential, according to him, as esthetic and political statements that destabilize the frames of meaning that define which lives should or should not be considered human. However, he points out that photojournalistic images still tend to represent polarized social forces, in which one must "eliminate" the other. Even so, these images form representative operations that shape the visible. Therefore, the solution is not to eliminate them but to maintain a reflective distance that allows us to understand events as processes in motion. An image is not an inert matter but an ongoing operation that produces regimes of visibility and legibility that can reiterate or shift the boundaries between the familiar and what has not yet been seen.

The analysis notes three elements present in the images: (1) there are similar patterns of representation, although the events are time-separated; (2) coverage focuses on the vulnerability of those portrayed, but there are also sequences of resistance, especially in face images and gestures; (3) individual images of suffering, loss, 
and grievance find a counterpoint in expressions of rage and reaction in the creation of the scene. Thus, the text accompanies these three axes of representations in photography. It is worth mentioning that, in the impossibility of reproducing all images throughout the text, the most representative of each situation was chosen. The complete indication of the image source in the materials is mentioned in the captions and after references.

\section{The temporal crossing of images}

The analyzed images go through a complex temporal crossing: there is a time gap of almost one year between the two sets of images belonging to the corpus of this research. These are events separated in time, each one endowed with its strength as a set of concatenated actions. However, if these time intervals are compressed, these events can become invisible due to the excess of continuous repetition of the uninterrupted flows of information related to violence, moral vulnerability, and precariousness that characterize the addressed subjects.

However, the logic of the analyzed images suggests proximity within the scope of representation that deserves closer reflection from the outline of what can be understood as a paradox between time and image: although separated by several months, the two sets of images appear to originate from the same event.

Why do two events, at different times, show similarities in the representation to the point that the images seem, in a hasty reading, interchangeable? It is speculation to advance some questioning whether the absence of changes is in the images or the scenario portrayed, such as the persistence of conditions in which the visual record is a reconstruction of events? It would be instigating to question whether anyone would notice a newscast using images from the previous year when reporting the floods that occur in some capitals every year during the rainy season. Thus, there is the problem of credibility and visuality ethics and the relationships between event and representation mediated by a plural image temporality in the forms of meaning construction. In Georges Didi-Huberman's words:

Before the image, however old it may be, the present never ceases to reshape, provided that the dispossession of the gaze has not entirely given way to the vain complacency of 
the "specialist". Before an image, however recent, however contemporary it may be, the past never ceases to reshape, since this image only becomes thinkable in construction of memory, if not of the obsession. (Didi-Huberman, 2017, p.10).

This "reconfiguration" suggested by the author presents itself as an analysis element by focusing on a synchronic perspective of news coverage. Strictly speaking, in an initial approximation, it was not the sets of images that were repeated, but the events: there were, in fact, two government operations in the area and, in both, the news coverage was present.

In the first instance, the production meanings of journalistic photography of the event are triggered: although distant, they result from similar procedures. Strictly speaking, it is the journalist's professional daily life: there is an event, and then excerpts, fragments, pieces of narratives collected by the professional are recorded at the time of presenting the product closed editorially for publication. Following the criteria of news and framing and the possibilities of elaborating a poetics of the event's coverage from each photographer's perspective, the moment of image production is considered, visual translation, limited as any discursive or narrative production of the event. In journalistic terms, it is coverage like all the others. There are production protocols understood as tacit, on the one hand, and appropriate to the specificity of each publication site, on the other.

In this aspect, the similarity of the coverages can find some resonances in the protocols for poetics elaboration of the journalistic image in the producer's scope. The producer is also inserted in a social fabric of meanings. Other elements are added, such as his expectations and professional competence, and a "habitus", as recalled by Barros and Martino (2003). Ana Paula da Rosa (2016, p.65) indicates that circulation "arises when there is an exchange, i.e., recognition of a value, whenever production and reception are said to agree. This implies that circulation is a process of equality in which production and recognition are linked".

What is expected concerning the "correct" coverage of a fact is known within the possibilities of journalistic practice. Also known are the meanings producible from changing expectations, seeking to assign other meanings to the images produced, and within a poetics of the photographic act. Thus, the images are repeated concerning the "expected" - they have already been seen and trivialized in previous coverage - and concomitantly, the same occurs concerning the 
"unexpected" in the images that show details, angles, movements, or unfamiliar gestures in the scene, other meanings of the event. These meanings are responsible for maintaining interest within the codes and protocols of journalism reading, and the unexpected becomes paradoxically part of the expectations.

One of the possibilities for presenting the similarity between the two sets of images refers, in this sense, to what can be effectively expected within the so-called "production routines" of journalism, privileging specific thematic selections and expected visualities to the detriment of others. In Mondzain's words (2009, p.30), "the image produces neither evidence nor truth and can only show what is produced by the gaze on it. The image reaches its visibility from the relationship established between those who produce it and who look at it". However, Marin (1998) points out that image power also derives from the expectation of a reality produced by its presence.

The limited temporality of establishing an urban "space within space", a region defined as "cracolândia", is another dimension to be highlighted. There is a time: this region did not exist at a time, and the operation refers to limiting its existence time to the present, projecting it into the future. However, there is also a time of the operation: these are localized days, with their duration constituting a few hours, usually starting just before dawn.

Finally, there is the time of journalistic coverage, perhaps the most singular of all: what L. C. Martino (2009) calls "media news" as the logical specificity of a chronology aimed at an organization within the order of the event. This time is the immediate time of the analyzed articles, published right after the police operations of 2017 and 2018. Thus, they keep their space within a time of the agenda and the journalistic matter. For journalism, these images do not "matter" until the moment of their publication, and possible immediate repercussions - possible later resonances of prestige in the so-called "journalistic field" are left aside, referring to Bourdieu (1997).

However, it is a permanence of images that, in repetition, is very close to a social repertoire of images associated with certain situations in which our evaluative moral framings are triggered (Prass $\&$ Rosa, 2018). In this sense, the large-scale representation seems to go beyond the singularities of each operation, constituting a similar imagery repertoire - which, in turn, is still related to what could be described as the expectation of images in circulation within the scope of social and media representations of life forms. 
Repetition is one of the factors on which the image strength rest, as well as their perpetuation beyond a present time in the form of a perspective of representation of the fact, and finds broad resonances in similar coverage, as recorded by McCarthy (1996), Bissel (2000), or Taylor (2000). The representation power is also manifested in the creation of expectations of its continued presence, or at least soon, indicating a representation.

Thus, what Fausto Neto (2010) would eventually call a "reading contract" is established based on the circulation of these images, their perpetuation as a possibility of representation, and the expectation of visibility of certain social phenomena when observed from a communicational scope. The crossing of time is articulated in tension with the possibilities of continuity of an expected and desired representation, resulting from a previous reading contract that authorizes the expectation of similarity.

The similarity between the two sets of images, in this way, is far from fortuitous. However, it seems to be interwoven in a web of representations and meanings in the intersection of spaces of production and circulation of events. If this perspective is correct, it would also enable us to observe how these expectation powers effectively become an act when the image becomes available for circulation in a digital space. There appears to be a possible engagement in this space with the image, observable in the form of comments, reappropriations, shares, or simply in the act of seeing the event. In the view of Mallmann et al. (2018, p.81), when analyzing a similar theme, "if images are, in this sense, text meta codes, they contribute decisively to the structuring of individual and collective imaginary. They do not portray an isolated scene only, but a framing of beliefs".

The similarity conditions between the two image sets can be seen in the power of the images to deal, at the same time, with meeting the expectations of scene visibility in which the photographed actions take place, on the one hand, and the sense of novelty and representation of an instant in the image sequences.

\section{Governmentality and biopolitical rationality of framings}

We argue in this work that in the Brazilian context, the poverty presented in images assumed in recent years a face shaped by framings that can be defined as biopolitical. They influence the 
orientation of collective judgments and conduct, intervening in the action and autonomy of the subjects and, thus, inventing specific management rationalities and techniques (Foucault, 1980).

According to Foucault (1980), biopower is divided into the practices of regulation and governance of individual bodies (biopower) and the practices of controlling a population, a collective (biopolitics). In this regard, the governance of collective bodies, the ability to control behaviors, modes of agency, and possibilities of action are related to how everyday, institutional, and intersubjective relationships are established. Foucault (2014, pp.132-133) states that power is a mode of action of some over others, defined in relationships and flows of interactions between subjects, without being incarnated in or even fixed to any position, individual/groups, or institutions.

The changes or transformations in the techniques of government are, as highlighted by Foucault (2003), the result of a political action that involves the production of different types of power and subjectivation relationships. Governmentality is supported by the biopolitical design ${ }^{2}$ of a form of police control that bets on the maximized productive capacity of docile and useful bodies. Such a form of rationality requires and rejects precariousness as a way of life, as an organizing and controlling principle through which biopolitical practices are based. In other words, it creates an evaluative framing that is nourished by the friction between polarized groups, among which one of them is accused of impeding the progress and the improvement of the community's life: impoverished individuals, drug addicts, homeless people, etc. would then be responsible for a nation's backwardness. For this very reason, the moral judgment that befalls them is emotional and reaffirms a priori condemnation, commonly reinforced by the speeches and narratives broadcast in the media.

As a form of rational intervention wielding political power
over men, the role of the police is to supply them with a bit of
extra life; and, by so doing, supply the state with a little extra
strength. This is done through the control of communication,
i.e., the typical activities of individuals (work, production,
exchange, commodities). (Foucault, 2003, pp.378-379).

The power relationships associated with biopolitics accentuate forms of control and inequality using discourses that deepen the moral judgment of lives. These discourses are based on moral standards legitimized by institutional codes limiting the subjects' possible field of action. This form of control, in our 
view, depends on how journalism offers framings and interpretive possibilities (modes of action or containment of these actions, options, and choices) to society.

The photojournalistic images analyzed here act strongly as signs that make up a network of statements structuring and articulating a form of biopolitics or the biopolitical government of collective bodies. The journalistic framing promotes a type of power that involves the modes of (in)visibility of subjects and groups, regulating the space and modes of their appearance and apprehension as lives worthy or unworthy of recognition and appreciation. In our view, specific images and their different framings, when conducting behaviors, configure a form of neoliberal governmentality that structures the eventual field of action of vulnerable subjects.

The vulnerabilities are outlined by biopolitical framings and moral framings based on a set of shared - but rarely stated assessments that encompass feelings that gradually define a type of common sense capable of defining who is or is not worthy of recognition, visibility, and listening. At the same time, these framings define the unique exposure of different groups and subjects to injury, aggression, rejection, and death (Butler, 2004).

According to Butler, "precarious life is the condition of being conditioned, in which one's life is always in some sense in the hands of the other" (2015, p.33). According to her, there are ways to distribute the vulnerability so that specific populations suffer from deficient social and economic nets of support and remain differently exposed to violence, violations, and death. Based on Butler's considerations in Frames of War, we can say that the process of institutional and media framing reaffirms a form of government of bodies through the prevalence of subalternating figurations in the image, which exposes the condition of vulnerability and precariousness of the subjects through control and underexposure mechanisms ${ }^{3}$, leading to social disappearance, impersonality, and dehumanization. Thus, according to her, a successful representation of the vulnerable subject should fail to capture the referent and evidence this failure.

In this respect, biopolitical framing is a technique of government or governmentality that shapes the scenes of appearance, preparing them to define exemplary subjects and groups, considered as parameters. Their project and way of life 
are seen as the antithesis of deviation and existences morally judged to be unworthy of consideration and appreciation. The photojournalistic images analyzed here, as we shall see, act strongly as signs that make up a network of statements that structure and articulate a form of biopolitics or the biopolitical government of collective bodies.

\title{
4 The context and the way of looking at the scene: biopolitics and control of precarious life
}

The genre of photography analyzed in this article frames the other - often an oppressed or scourged one. As indicated by SáCarvalho and Lissovsky:

\begin{abstract}
Talking about the other, portraying the other, however, seems to have lost its legitimacy. The accusations to this kind of photograph range from criticism to esthetics (a beautiful photo diverts attention from the appalling theme and directs it towards the vehicle itself) to ideological manipulation, paternalism, and interest on the part of the photographer. (Sá-Carvalho \& Lissovsky, 2008, p.78).
\end{abstract}

The construction of the image is articulated between several dimensions present within a mimetic but also poetic re-elaboration of what immediately appears as "real" at the moment of the image's apprehension. This happens at the tension intersection between the "real" in front of the cameras and the photographer's view. At the time of registration, the choice is as essential as the former possibilities of interpretation and effects imagined by the image's author. According to Joly (2007), the meaning of image elements is strengthened by its presence and the absence of others.

When looking at the images of the analyzed reports for the first time, a recurring point is the symbols of disorder and dirt (Figure 1). Things thrown to the floor like plastics, clothes, papers, garbage bags, and even chairs, tables, and sofas can be seen in several images, scattered on the street floor devoid of any other identification except as "cracolândia". Amid the remains of debris, people are also seen and become almost indistinguishable. 
Figure 1 - Representation of the environment.

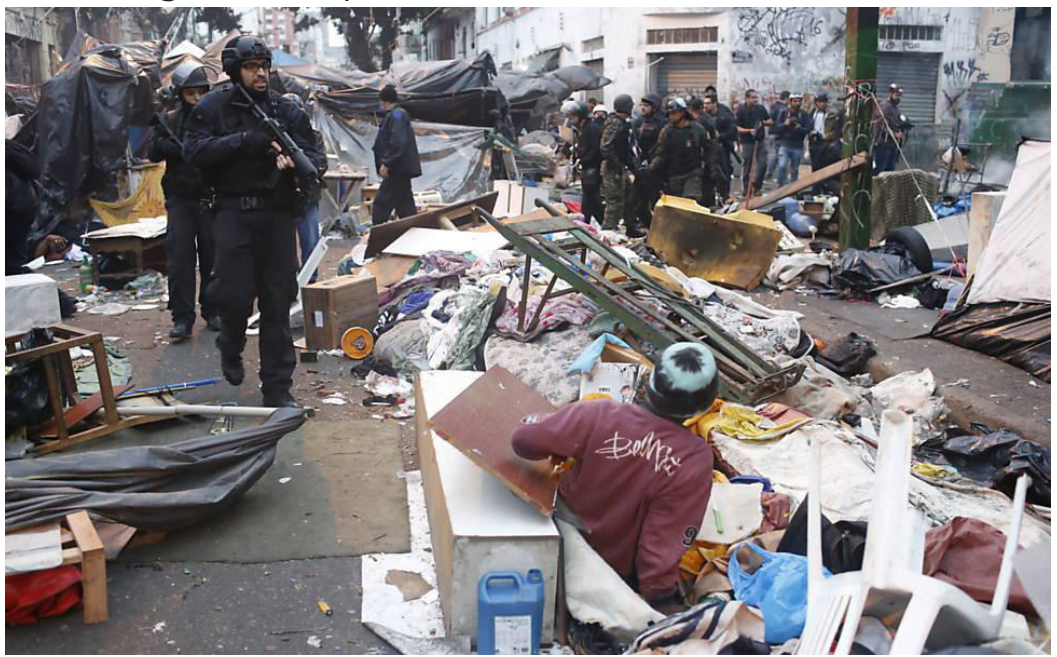

Photo: Danilo Verpa/Folhapress (2017) .

There is a symbolic inversion of a principle dear to modernity: hygiene. In the analyzed images, not only the dirt on the floor but the whole place is noteworthy. Users' clothes are beaten, almost always disproportionate to the bodies that inhabit them, things and objects apparently unrelated to the place - since they should belong to a space of intimacy - are piled up like garbage, similar to the poor conditions for the conservation of surrounding buildings. This sample of little general cleaning shows how important the sense of seeking to clean the user and their environment.

Oberling and Pinto (2015) indicate sanitation as an essential aspect of drug policies, something that, as Carvalho (2011) points out, dates back to the $19^{\text {th }}$ century. We cannot fail to comment here on the type of morality that animates these biopolitical control operations, defined to evaluate the strategies of urban "cleaning" and also the forms of life and the trajectories of subjects considered "disposable". Their lives do not deserve recognition in the face of a device for managing poverty and urban violence. These lives are not only disposable, but they are threats to the lives of those who count as dignified and respectable citizens and who want distinction and protection against those who inhabit spaces considered to be condemned and "condemnable".

In many of the photographs analyzed, the image of these spaces is composed of large groups of users. This happens in two 
ways: in a joint movement, usually walking, or with the group stopped, and each individual, together and isolated at the same time, practicing their activity. As a moving group, images are taken in an open plan, which covers as many people as possible; when stopped, the photos focus on smaller groups in the foreground but keep the image of larger groups in the background (Figure 2).

Figure $\mathbf{2}$ - Representation of user groups.

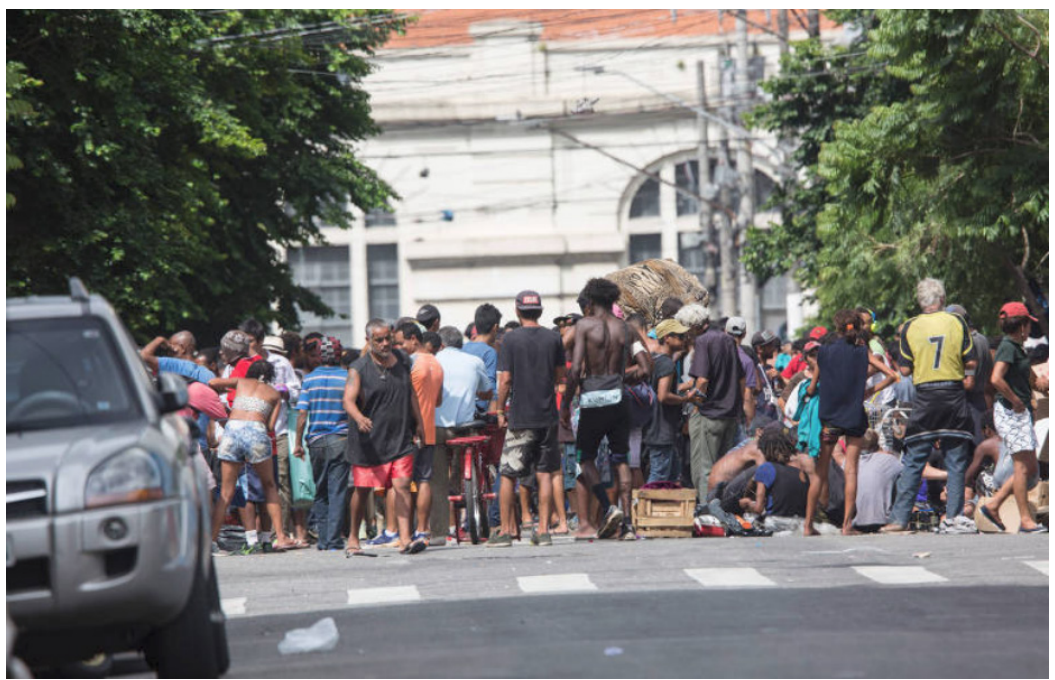

Photo: Diego Padgurschi/Folhapress (2018)5.

In this type of representation, it is possible to notice an erasure of individual actions, stripping the subjects of any personal characteristics and making it difficult to understand them as human beings - devoid of a story, a narrative, or a name. Their history is erased so that the story of the group can be told. As Oberling and Pinto (2015, p.170) describe, users are seen as unable to decide their course, and therefore, they are not reserved rights. If they are individuals without rights, the State's actions of repression against these groups are only for the sake of an alleged common good.

The impersonality used to address this user demonstrates the strength of the discourse and how the subject's objectification as "zombie" or "undead" makes it impossible to even reflect on the type of service that will be made available to them, as there is no need for it. We are talking about "zombies" and "undead" who do not need humanized care or some care but are removed, fought so that they stop scaring people on the streets. (Wurdig \& Motta, 2014, p.440). 
If, at the same time, the "zombified" image of the drug user contributes to a stereotyping that dehumanizes him, the misery tone also evokes a human sense for him and even, in a peculiar inversion, inserts him into a group narrative.

Sá-Carvalho and Lissovsky (2008, p.84) explain that the misery and suffering portrayed in the images are unique, insofar as they should arouse pity in the viewer at the same time they become political aspects when the image evokes "a plurality of similar situations of suffering". In this sense, the symbols of misery and suffering are indicators that go beyond arousing compassion in the reader: they also indicate the social problem aspect of the situation (Figures 2 and 3).

It is also important to mention that these zombie users without names and history appear before us through the mediation of images that offer no opportunity for doubt or contemplation: condemnatory judgments are triggered instantly. There is no opening in these images for a "moral undecidability" (Perlini, 2012 ), i.e., an equivocal, unresolved moral assessment, which calls for critical reflection and questions parameters and assumptions that outline legibility and intelligibility to the world. An image that mobilizes indecision and questions the place of "virtuous jury" occupied by the recipients does not accept quick explanations. It does not adhere so quickly to the moral evaluations of the spectators (Perlini, 2012). It escapes schematics, dialogues with other images and unveils some of the dynamics of the devices that make them exist.

The images we have analyzed here do not establish a space of "moral undecidability": they do not make the viewer hesitate or doubt their beliefs. They are images that tell; they causally organize the facts instead of evoking by the report and by the failure of the report to capture the complexities of the ways of life. They are images that explain and judge, reiterate pre-established framings instead of suggesting and preserving the complex gesture of apprehending and recognizing instances of otherness (Reis Filho, $2017)$. In this regard, few aspects of these images make us sensitive, disarm the gaze, and make imaginative knowledge work in the face of the "deimagination machinery" (Reis Filho, 2012) that seems to manufacture biopolitical framings. Therefore, the dialectization of the visible is a process that requires constant interpellation from the viewer, requires imagination, requires a contemplative look, 
positioned against the erasure of the subjects and their ways of life (Didi-Huberman, 2017).

Figure 3 - Approaching the precarious living conditions.

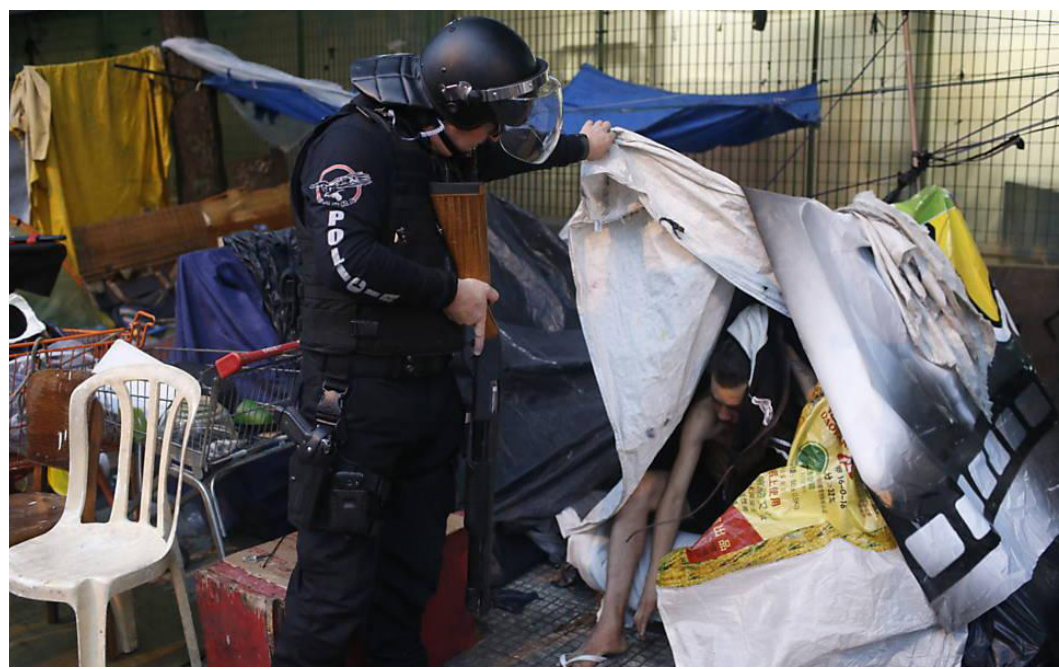

Source: Danilo Verpa/Folhapress (2017)6.

On the other hand, this aspect should be noted as containing a critical tone that is very characteristic of prohibitive and punitive policy. The images, instead of being used to raise awareness about the situation, end up serving the elite fetishes regarding the exclusion of these layers, as explained by Forin Junior and Boni:

\begin{abstract}
Photojournalists and communication vehicles use the images of the miserable. The success of these works indeed grants excellent profitability to the images' owners, without the benefits being reverted to the individuals portrayed or to the class they represent. The elites contemplate the photographs to nourish the libido through social exclusion and the "charm" it awakens. (Forin Junior \& Boni, 2006, p.43).
\end{abstract}

The unmistakable elements of violence in the images are allied to the scenes of misery. Whether these symbols of violence are materialized, such as the users' facial and bodily expressions, such as images of smoke, fire, or weapons, the presence of the police, they suggest the assimilation of the situation as intrinsically violent, with echoes of pain and suffering that accompany the whole scenario. 
Figure 4 - Use of police force and fire destruction of makeshift homes.

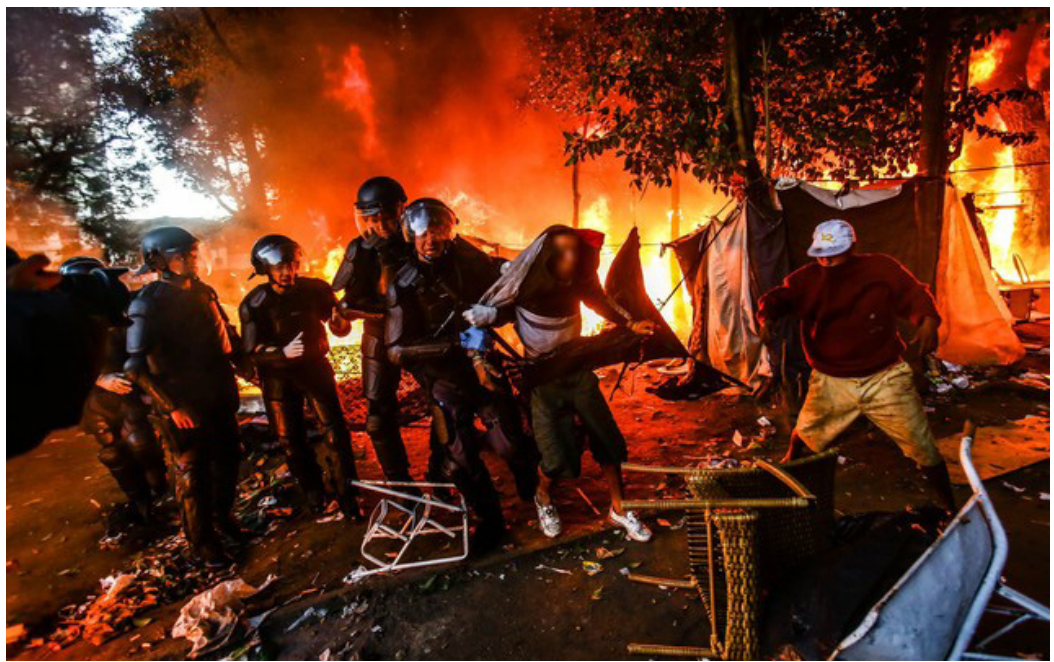

Photo: Leonardo Benassatto/Framephoto/Estadão Conteúdo (2017)7.

Violence images are often interspersed with images of "zombification", and the outline of the large group, when in movement or placed in front of symbols of violence, adds a tone of violence (Figure 4). Oberling and Pinto (2015, p.169) understood this materiality and group personification of violence as "two great relational axes, in the collective/social-crack and expansion of violence; and in individual-drugs and destruction".

It is worth mentioning that the images of truculence in the police action reach a higher rate of comments on the news portals we surveyed. We could argue, along with Rosa (2017, p.2), that the persistence of a given portrait model of these groups is strongly linked to "value operations that prolong the circulation of certain images to the detriment of others". However, the images do not reach comprehensive visibility and social spread for free: they integrate and feed a circulation system based on shared moral framings of judgment and evaluation that usually precedes them. This does not mean that the moral devices for accepting or rejecting images are immutable. However, it does reveal that the carefully chosen framings to compose "pictures" of vulnerable lives are those in which there is a behavioral, evaluative, and moral component that allows access to interpretive formulas, shared and widely accepted as valid. Thus, what distinguishes an 
image intended for the biopolitical control of bodies (Foucault, 1980) from other images is its power to emerge from framings that encourage the collective recognition of codes and patterns integrating posture and behavioral assessments. It reinforces an economic morality guided by the production, circulation, and appropriation of values and affections about a given issue.

In a few images, drug users appear as individuals. In these cases, the tone of the image is related to the violence of selfdestruction, as if in a warning to the population, these images show users in degrading situations, consuming or buying drugs amid chaos. The analyses refer to a recurring history of criminalization, prohibition, and punishment. Reassembly of a genealogy of practices and speeches associated with the theme is outlined (Figure 5).

Figure $\mathbf{5}$ - The individually portrayed user.

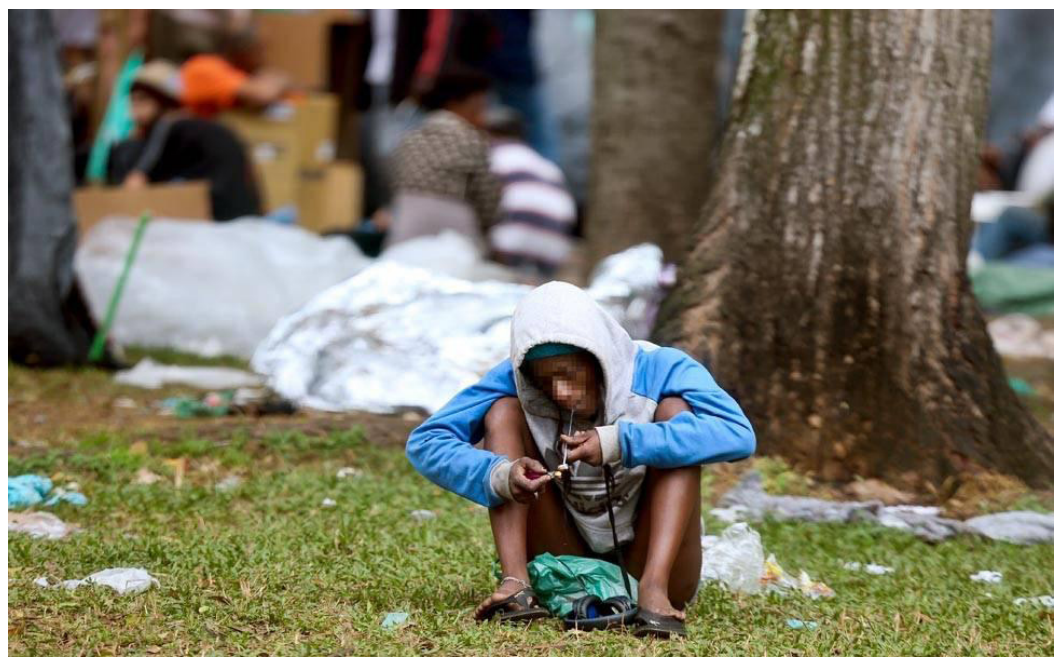

Photo: Zanone Fraissat/Folhapress (2017) .

How the media treat the drug phenomenon in Brazil seems to be related to the course of discourse and practice related to prohibition - called "prohibitionism" - in the country. Not indifferent to the world scene of combating drugs, which dates from the beginning of the $20^{\text {th }}$ century, with the Shanghai and The Hague conferences, there is also a trajectory in Brazil towards the idea of a national fight against drug commercialization and use (Delmanto, 2015; Carvalho, 2011). 
Another component is linked to the tangent and subsequent incorporation of medicine discourse into the fight against drugs in Brazil and globally. The State expresses its concern about the influence of psychoactive substances on people's health (Delmanto, 2015; Carvalho, 2011), within a movement understood by Foucault (1980) as part of the biopolitics of body control. At this juncture, the scenario, year after year, occurs on drug consumption and trade in the conception of criminalization of drugs and their users.

Analyses of the media coverage in Brazil of psychoactive substances and the related policies suggests a framing derived from the view on prohibition in the media approach and the public's thinking:

\begin{abstract}
Based on reports carried out on the streets of large cities and slums/peripheries, images of poor and decrepit young people are presented in the drug retail trade and/or use. Also, images of crack "zombies" roaming the streets of big cities, young drug dealers who dominate territories with heavy weapons. All of this allows their analyses to be guided by direct observation of the facts narrated. It is directed to a moral assessment of these problems due to the State's abandonment of the poor areas and facilitation for criminal behavior. Crime and drug use appear as a result of the ineffectiveness of state control. The solution would be to strengthen institutions of social control, the State to sanitize and occupy these areas and strengthen the apparatus for repressive police agencies and the criminal justice system. (Oberling \& Pinto, 2015, p.163).
\end{abstract}

The paths of media representation related to the parties involved with drug use appear to be related to the user-dealer association made by the media and the public. As explained by Ronzani et al. (2009), in the public's view, this association leads to a stigmatization of the first group, making it even more challenging to access fundamental rights and being one of the directions of public policy guidance for these groups. According to the authors, "drug addiction would constitute a problem without a cure, with the addict seen as someone with "character deficiency"' (RONZANI et al., 2009, p.1752).

As shown by Oberling and Pinto (2015, p.165), reports published in the Brazilian media often reinforce punitive thinking in primary criminalization and a secondary one. This reinforcement occurs in the presentation of the argument that "by sanctioning tougher laws against drug traffickers and users who repress these agents excessively, greater urban security will be obtained against violence and common felony". 
In these authors' view, the media environment reflects and expands notions that have remained as regulators of the agenda on the use and trafficking of drugs in Brazil since the $20^{\text {th }}$ century, articulating between the scenario seen and the perspective described.

\section{The construction of the scene and the vocality of the gesture}

What are the life forms portrayed in these images? What is presented, as a whole, about users, State agents and the interrelationship between all? These are two scenes very delimited in terms of the various temporalities present in the representation of these images. Considering the visible requires an instant to locate the duration of a time and space that delimit the sets of images made objects in this research, especially as the shape of the representations tends to overcome time barriers.

The visuality of the photographs shows the event from a scene in which there are frames, characters, actions, and focuses aimed at building a representation that is both close and related to the expectations of an audience that presents itself as absolutely external to what is happening, as Adams (1980) already argued when talking about the framing of photojournalism.

The images of the operations suggest an analysis key based on the direction of the users' view of the set. Not all photos show the face or, specifically, the gaze of the users. A look that turns the face into a face (appeal or demand to listen) in what can be visible from the being.

The images often offer a clear view of the face of all the people involved. This visible, human face that speaks and claims (Figure 6) can be understood as one of the focuses of the interpellation and summoning relationships present in the images. Several questions can be addressed about these vectors of summoning and directing the gaze, insofar as they constitute one of the founding acts of the relationship of otherness to which an answer is sought, constituting an introductory gesture of a scene of interpellation (Butler, 2015). 
Figure 6 - Parallel interpellation.

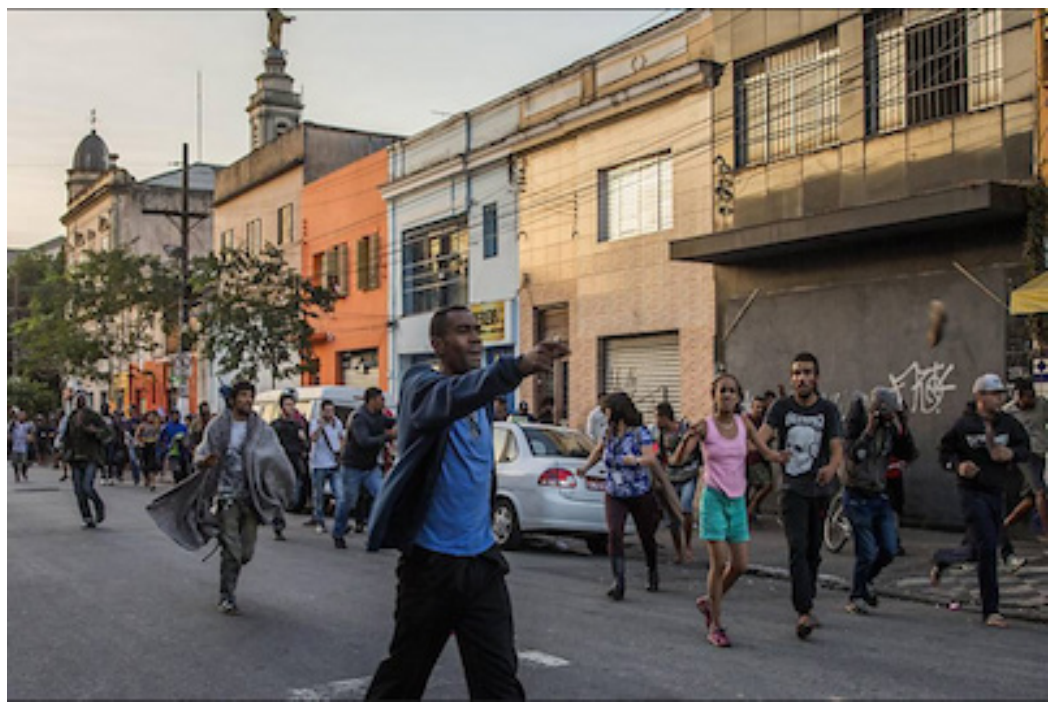

Photo: Marilene Bergamo / Folha Press (2017) ${ }^{9}$.

To whom is this look directed? Is there, before that, a direction of the gaze, focused on the apprehension of something? Moreover, if there is an answer, from where does it come? As Ana Paula da Rosa (2016, p.61) recalls, "the image reveals more of those who contemplate it than of those who produced it".

In the observation of the image, the interrelationship between the characters in the image presents itself as something always unexpected, constituting an instant that lasts forever. It is also shown as an expectation of response. In the face of the interpellation of one of the people, how does the other react? Is there an answer, or is the way of life at that moment, without being constituted as otherness, out of any expectation of putting himself in the relationship?

The images are presented within a complex relational game between the ways of seeing, which may not cease to be constitutive of life forms or their representations. There are at least two dimensions of these lines of force present in the image. On the one hand, we have the interlocutions of the gaze between the portrayed people. On the other hand, perhaps more strongly, the moment when there is a break in the figuration of a scenario, of the "fourth wall". Someone's gaze is directed towards the camera lens. Therefore, the visible interrogation of an "outside" that, staying in the scene, creates 
concomitantly a feeling of interrogation, question, and participation of those observing the image.

There is, still, the silence of non-gaze, the seemingly empty gaze, directed to nowhere that seems to be configured in the absence of any understanding about what is happening: looking towards the scene, to an environment constantly portrayed as miserable, in which the centrality of the human is called into question in the face of the desolation scenario: the metaphor of a "war zone" (Butler, 2015) is presented here. It is worth developing, briefly, each of these gestures of interlocution of the gaze revealed during the analysis.

In the first case, in many images, the relationship of looks is observed between the users and the State representatives, mainly police and healthcare and social service agents. These photographs show the individualized face of the user: even in a group, and perhaps it is still a kind of visual paradox already problematized above, the expression of each one and each one of them presents itself as unique, just as there is no uniformity in the way to wear or as a whole appearance.

In common, among the users, the thinness of the bodies, the consequences of the situation in which they find themselves, and the interlocution based on a speech that is not heard, but presumed, almost guessed, suggested by the image of open mouths, expressions of vocalization, directed at other people. As Marie-José Mondzain (2009, p.19) defines it, "when we say that an image is violent, we suggest that it can directly act on a subject outside of any linguistic mediation".

Here, the photographic act is almost like synesthesia in the evocation of a sound, or, still, of a face that becomes sonorous. One imagines the voice present in the gesturality of facial expression oriented to another person, a kind of sonorous appeal registered by the visual. At least in two of his classic works on the voice, Zumthor (2018) recalls an aspect of vocality "performance". Surpassing the sonorous universe, it also constitutes corporeality affirmed in the gesture, movement, and, in the case of the images analyzed, on the face from which that voice is emitted. "Directed word is a bodily word. It is less the meaning than the voice, and with the voice - or in silence - the gesture, the posture, the movement of the body", reminds Nancy (2016, p.233).

One cannot go far beyond imagining the sound set present in each of the images: we have not yet been able to freeze the sound 
of the instant in the way that light does with the image, but that is not precisely the point here. It is not about thinking about sound as an "environment". Instead, the voice is an element of evocation present in the images, the voice appearing when addressed to another person. Throughout the sequences of photographs, these expressions of mouth openings are present towards another person facing him and, in a generic way, as an exclamation when faced with a situation. There are rare, presumed exchanges of speech among the users themselves.

Is there an answer? Judging by the images, they are rare. The summons of the voice presumed in the images spread throughout the scene without actually constituting any relationship. Thus, the look returns to the protagonism insofar as the element of contribution concerning the other and the world. The scenes drawn in the photos are always interpellation: the answer, when there is one, is also in the space of the gaze, but it is another look, constituted within a discourse with the force of law. The asymmetry of the looks resists and fits the directions (Figure 7).

Figure 7: Interpellation and asymmetry of looks - solidarity and compassion for the presumed victim.

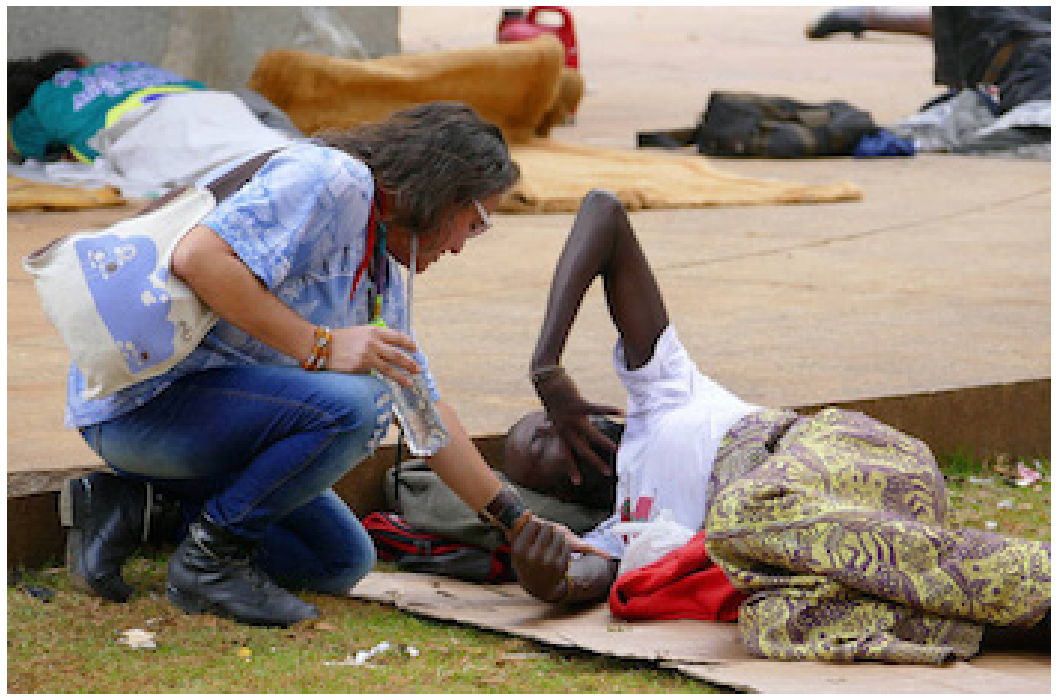

Photo: Jorge Araujo / Folhapress (2018) ${ }^{10}$.

However, the users' gaze and their facial expressions are not just for questioning. They also present themselves as the visuality of 
moments of indignation, revolt, and refusal. This other movement can be seen in the stance of looks that, supported by gestures and the movement of bodies, seek to become agents of an unexpected situation. In these cases, the interrogation is articulated, or even gives way, affirming a look searching the surroundings and refusing passivity in the face of the event.

\begin{abstract}
Therefore, what we ignore, the appearing-disappearing arrives in the space-time of the place where the meaning between bodies is uttered - the meaning can only take place "between" and from one to, can only be felt for the other. This space-time is what we call "scene"; it is the proskénion over which bodies move forward to present what each body does as a body: to present itself in its appearance and its disappearance, to present the action - the "drama" - of a sharing of meaning. (Nancy, 2016, p. 232).
\end{abstract}

The moment of vulnerability expressed in the interpellation that it interrogates becomes a space for affirming the established way of life in contrast to the operation. There is no passivity but latent conflict. The scene now becomes an open conflict, and the photographs do not fail to show this. Asymmetrical, the confrontation is made visible in the exchange of gazes between the participants. It is a typical representation of the violence in photojournalism: the individual, composed of the diversity of his individuality (each with a type of clothing, faces exposed or hidden, the impossibility of finding any pattern) in contrast to the State shown in denotative uniformity (use of uniforms and identifications) and connotative (regularity of the law and attitudes; planning of action).

Prass and Rosa (2018, p.230) recall the "gaps that can be produced and perceived with the dissemination of images since the contexts are not captured. Therefore, distortions are almost a condition". The repercussion and circulation of images, underline the authors (2018, p.234), "reveals not only the rawness of the image, the pain, or the shock" but also "exposes the process of producing meaning in its total absence of control or regulation".

Interlocution and indignation seem to be two of the main ways of observing the relationship between the people portrayed in the photographs, referred to in the gaze directed towards the other and gets some kind of response. In the aforementioned relational game, the reader who observes this image is faced with a more or less closed picture, with a constituent and constitutive scene of meaning at the same time that it is open to an infinity of other possible meanings. 
There is, however, a second moment of directing the user's gaze. It occurs when he moves from the other figures in the scene and turns, in a movement, to those who are supposed to observe him. In these images, the users' gaze, in their faces' visibility, turns to the exterior for those who look (Figure 8). In an expressive and perhaps unexpected literality of Didi-Huberman's (2015) proposition, at this moment, the image seems to look at who is in front of it. The individual's gaze moves out of the spatial picture of the photograph and calls for participation in the scene: the "call", in the etymological sense of "calling", is related to a direction that creates, or seeks to create, no longer interlocution with the other characters within the image, but with the one who, by definition, would need to maintain an "objective" distance from what he sees - the reader.

Figure 8: Looking out of the scene.

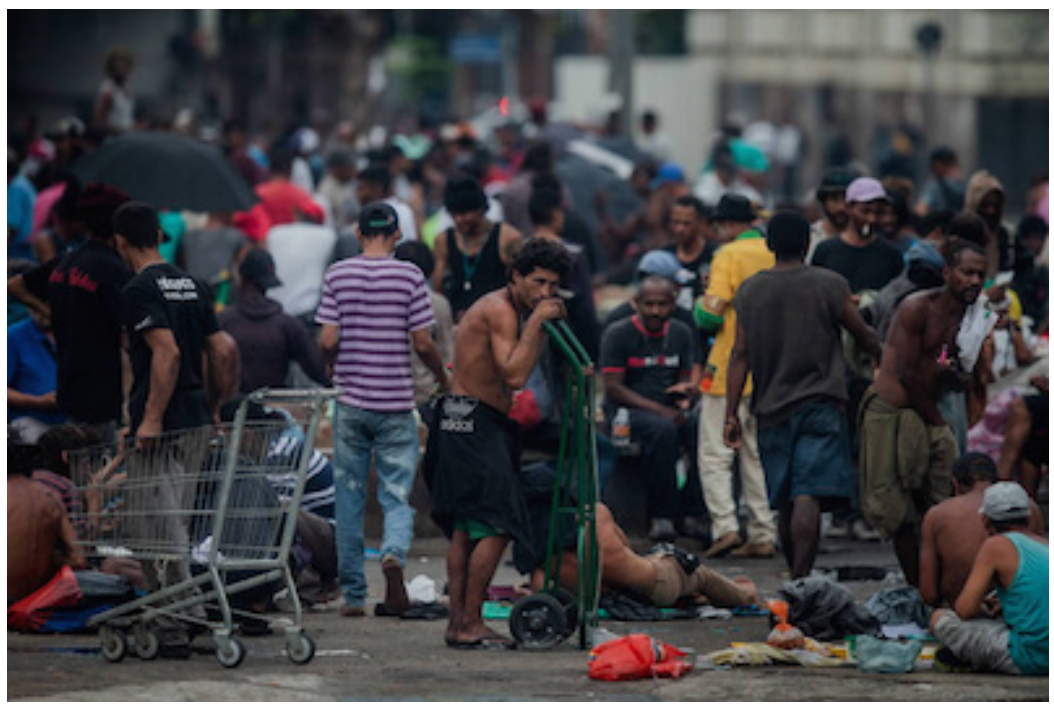

Photo: Eduardo Zanelli/Folhapress (2017) ${ }^{11}$.

It is also possible to observe something similar to what Mallmann et al. (2018, p.86) found in their research: "The rawness of the photographs, combined with the limited amount of text in the posts, gives a character of immediacy and reality without intervention to the page". Moreover, they continue: "The construction of the social 
imaginary, based on photos, constitutes a two-way street. On the one hand, the rawness of the content allows interactions to build meanings not contained (at least explicitly) in publications".

This gaze challenges us by revealing a first person who is looking at the eyes of the other. The visible face allows us to observe the establishment of perplexity regimes, referring to sharing a situation where the person portrayed was a character. His face becomes the face of an expression of identity, photographed from the front, looking at the camera. Perhaps, even more, of identification, when he ceases to be the "character" of a photo and establishes himself as a person who questions who sees and challenges to think about their humanity. He remains anonymous, no doubt, but he comes close, by the face, to the condition of similarity with the one who looks at the photograph. It is an approach marked by the correlation of a subjectivity that manifests itself in the "real" person's gaze.

A third direction of the users' gaze in the photos also seems to be the most frequent: the focus on the surrounding environment, especially considering what is close, of the immediate result of the operation. At this moment, the user's human relationship with other people, or even with the camera lens, seems to cease. It is replaced by a subjective apprehension of the situation, in which the gaze challenges the movement of a reality that escapes immediate comprehension. However, neither by this ceases to impose itself with redoubled strength at every moment.

The camera movement, in this sense, is not in the immediate course of capturing the relationship with the other, but the gaze that reveals surprise, consternation, and indignation amid the event. This gaze is not shown as directed at something specific: none of the photos show the interaction with objects or the look defined at something. Instead, it is about looking at a group that insists on escaping any apprehension. Therefore, the subject's gaze is directed to the scene itself, intending to understand and act, recorded by the photographer as an interaction between the person and surroundings. This direction is also the most generic: the gaze that became voice at first, and then the call of the second person, here becomes the attempt to recognize the environment and, in certain reflexivity, himself. 


\section{Final considerations}

The shocking image of the event is softened by an indifference cultivated, paradoxically, by the immediate shock that haunts. However, it does not perpetuate itself in time, allowing the repetition of the act and the presence, each time, of a set of similar images to the previous ones. These images eventually also present themselves as an immediate shock factor and then add to the accumulation of images of pain and suffering. Alternatively, as Rosa defines (2016):

[...] we live in a time when images no longer belong to those portrayed, but rather to the very game of media circulation that comes to hold power over the image of the individual or the event, the power to exhibit or not, the power to show again, to reinsert, to erase, to work-through. (Rosa, 2016, p.76).

The "becoming present" of the act of image "re-presentation" is temporarily attenuated in the mediated form of an eternal here and now of the visibility of the media image. It occurs, particularly in the digital media environment. The instant eternity is manifested in the dispersion of "rotating the screen", passing through the image that shocks the visibility of a precarious existence form. Paradoxically, there is an expected novelty, a surprise that is not surprising seeing the image replaced by another. This occurs within a protocol of reading equivalence that can lead to the most different reactions according to the degree of engagement caused by the image.

The artificial "reality" effect in the sense of an artificium, "the result of an art", provoked like all others. The gaze that appears to be "outward" does not in any way escape the scene or its environment. The "outside" perspective is presented only to those looking, not to the scene participant who, at that moment, saw or would have seen a press photographer equally in the scene. Perhaps a few meters away, the photographer points his camera for a brief moment and captures an expression, a gaze, a gesture.

The idea of "reality" seems to be asserting itself, thus, from a perhaps paradoxical displacement: the photographer and the photographed, inserted in the scene in which the event is defined; there is an illusion of direction towards a supposed "first-person" built by the look of the photographer who, at that moment, presents himself as the eyes of future readers. The photographed person saw a photographer in a critical situation: what is seen in photography is a gaze pointed outward the scene. 
The camera capture is also the reminder that another world is represented by the journalist: that of people who, in no way belonging to that place, nevertheless do not cease to want to see it. Although obtained and located "inside", the gaze is directed towards at first a metaphorical "outside". It becomes concrete when the photo participates in the larger context of news coverage.

It is possible, here, to resume something from the initial lines of the text. Sontag (2003) recalls that the negative image has a long history, forming almost what one could risk defining as a poetics of the negative characterized, among other elements, by the indifference resulting from repetition. Without being identical, it is guided by the fact that it is seen but not felt, a sentient form from which sense is absent.

The analyses carried out by us reveal a way of operating the photojournalistic images of vulnerable subjects that do little to challenge the hierarchical way of presenting reality. Biopolitical framings disarm the work of visibility regimes trying to displace the gaze, reaffirming the consensual legibility of the statement of images. It is essential to highlight that the representative images are not outside a dialectical dynamic that places them in the face of questions and resistance. As Reis Filho (2019) explains, it is not a question of eliminating representation as a work operation that shapes the visible, but of producing and maintaining a threshold that allows the development of hospitality and ethics of responsibility towards the otherness that comes to us through the images.

An image is a composite of several heterogeneous elements that, articulated, achieve a resonance, a complex operation for the manufacture of meanings and understandings about the world. That is why we believe that photojournalistic images can be understood in a broader way than the sum of their visible elements: by shifting the gaze from the image's denotative sense, it is possible to look at it and perceive the figuration of the subjects: their existence as human beings submitted to pain, suffering, and precariousness already presuppose the establishment of other imaginative possibilities, of another type of ethical connection with the lives narrated by the journalistic text. We argue, together with Didi-Huberman (2015), that the image can "make sensitive" our way of apprehending reality, i.e., making accessible a dimension of vulnerable subjects' way of life usually erased in violent contact with the police order. 


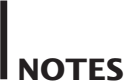

1 This article is the result of research supported by CAPES, CNPq, and Fapemig.

2 According to Foucault (1980), biopower is divided into the practices of regulation and governance of individual bodies (biopower) and the practices of controlling a population, a collective (biopolitics). In this regard, the governance of collective bodies, the ability to control behaviors, modes of agency, and possibilities of action are related to how every day, institutional, and intersubjective relationships are established. Foucault (2014) states that power is a mode of action of some over others, defined in relationships and flows of interactions between subjects, without being incarnated in or even fixed to any position, individual/ groups, or institutions.

3 "Under-exposition deprives us of the means to see, pure and simply, that which might be at stake. [...] But over-exposition is not worth much more: too much light makes one blind. Peoples exposed to stereotype rumination of images are, they also, exposed to disappear. [...] If the peoples are exposed to disappear, this is also due to the fact of the construction of discourses due to which, ceasing to see anything, we may yet believe that everything remains accessible, everything remains visible and, as one uses to say, under control”. (Didi-Huberman, 2011, pp.41-45)

4 Caption: One of the main objectives of the policy is to dismantle the drug's free market. Source: Pagnan, R., \& Verpa, D. (2017, May 21). Polícia faz megaoperação de combate ao tráfico na Cracolândia. Folha de S.Paulo. Retrieved from https://m.folha. uol.com.br/gallery/\#galeria=50633-policia-faz-operacao-nacracolandia-em-sp,foto=687794,ref=undefined,fotografia_url=// fotografia.folha.uol.com.br/galerias/50633-policia-faz-operacaona-cracolandia-em-sp

5 Caption: Regulars of the Cracolândia region collect belongings during street cleaning; moment concentrates tension, and conflicts with Metropolitan Civil Guard have been constant. Source: Amâncio, T. (2018, Feb. 1). Cracolândia do centro de SP diminui, mas vive conflitos diários. Folha de S.Paulo. Retrieved from https:// fotografia.folha.uol.com.br/galerias/nova/1591147249340761cracolandia-em-2018\#foto-1591147249527819 
6 Caption: Crack users are approached in police action. Source: Pagnan, R., \& Verpa, D. (2017, May 21 de maio). Polícia faz megaoperação de combate ao tráfico na Cracolândia. Folha de S.Paulo. Retrieved from https://m.folha.uol.com.br/gallery/\#galeria=50633-policiafaz-operacao-na-cracolandia-em-sp,foto=687794, ref=undefined, fo tografia_url=//fotografia.folha.uol.com.br/galerias/50633-policiafaz-operacao-na-cracolandia-em-sp

7 Caption: Military police remove drug users from Princesa Isabel Square, in Cracolândia. Source: Portal G1 . (2017, June 11. Cracolândia é alvo de nova operação policial neste domingo. Retrieved from https://g1.globo.com/sao-paulo/noticia/cracolandia-e-alvo-denova-operacao-policial-neste-domingo.ghtml

8 Caption: Drug users occupy Princesa Isabel square, in the central region, after eviction from cracolândia. Source: Maia, D. (2017, May 26). Nova cracolândia no centro de SP dobra de tamanho em apenas um dia. Folha de S.Paulo. Retrieved from https://m. folha. uol.com.br/gallery/\#galeria=50687-nova-cracolandia,foto=689 615 ,ref=undefined,fotografia_url=//fotografia.folha.uol.com.br/ galerias/50687-nova-cracolandia

9 Caption: Two days of joint action by the City Hall and the State that evicted drug users and homeless people from the cracolândia region, users are concentrated in Princesa Isabel Square. Police officers arrive at the end of the afternoon, search some individuals, a tense atmosphere takes hold of the flow, and they leave the square in the direction of the streets from which they left on Sunday. Source: Pagnan, R., \& Verpa, D. (2017, May 21). Polícia faz megaoperação de combate ao tráfico na Cracolândia. Folha de S.Paulo. Retrieved from https://m.folha. uol.com.br/gallery/\#galeria=50633-policia-faz-operacao-nacracolandia-em-sp,foto=687794,ref=undefined,fotografia_url=// fotografia.folha.uol.com.br/galerias/50633-policia-faz-operacaona-cracolandia-em-sp | This photograph was reproduced again in the following matter: Rodrigues, A., \& Machado, L. (2017, May 28). Semana perdida na cracolândia frustra novo programa de Doria. Folha de S.Paulo. Retrieved from www1 folha.uol.com.br/ cotidiano/2017/05/1888126-semana-perdida-na-cracolandiafrustra-programa-de-doria.shtml

10 Caption: Healthcare agents work with crack users in Princesa Isabel Square. Source: Pagnan, R. (2018, November 28). Polícia prende 4 em operação contra no tráfico na cracolândia do centro 
de SP. Folha de S.Paulo. Retrieved from https://www1.folha.uol. com.br/cotidiano/2018/11/policia-faz-operacao-para-prendertraficantes-na-cracolandia-do-centro-de-sp.shtml

11 Caption: Drug addicts and homeless drug users migrated to the Square two blocks from the old cracolândia. Source: Rodrigues, A., \& Machado, L. (2017, May 28). Semana perdida na cracolândia frustra novo programa de Doria. Folha de S.Paulo. Retrieved from www 1.folha.uol.com.br/cotidiano/2017/05/1888126-semanaperdida-na-cracolandia-frustra-programa-de-doria.shtml

\section{IREFRENCES}

Adams, R., Copeland, G. A., Fish, M. J., \& Hughes, M. (1980). The effect of framing on Selection of Photographs of men and women. Journalism Quarterly, 57(3), 463-467. DOI: 10.1177/107769908005700313

Barcelos, J. D. (2009). Fotojornalismo: Dor e Sofrimento. Estudo de caso do World Press Photo of the Year 1955-2008 [master thesis, Universidade de Coimbra]. UC Scientific Repository.

Barros, C., \& Martino, L. M. S. (2003). O habitus na Comunicação. São Paulo: Paulus.

Biondi, A. G., \& Marques, A. C. S. (2015). Suffering Body: narrative tensions for a politics of the images in photojournalism, Brazilian Journalism Research, 11(2), 110-127. DOI: 10.25200/BJR.v1 ln2.2015.848

Bissel, K. (2000). A return to 'Mr. Gates': Photography and objectivity. Newspaper Research Journal, 21 (3), 81-93. DOI: $10.1177 / 073953290002100307$

Bourdieu, P. (1997). Sobre a televisão. Rio de Janeiro: Jorge Zahar Editor.

Buitoni, D. (2011). Fotografia e jornalismo: a informação pela imagem. São Paulo: Saraiva.

Butler, J. (2004). Precarious Life: The Powers of Mourning and Violence. New York: Verso.

Butler, J. (2014). Quadros de Guerra. Rio de Janeiro: Civilização Brasileira.

Butler, J. (2015). Relatar a si mesmo. Crítica da violência ética. São Paulo: Autêntica.

Butler, J. (2016). Corpos em movimento. Rio de Janeiro: Civilização 
Brasileira.

Caron, C. (2007). Humaniser le regard. Du photojournalisme humanitaire à l'usage humanitaire de la photographie. Commposite, 1(1), 1-19. Retrieved from www.commposite.org/index.php/revue/ article/view/89

Carvalho, J. C. (2011). Uma história política da criminalização das drogas no Brasil: a construção de uma política social. Proceedings of the VI Semana de História e III Seminário Nacional de História: Política, cultura e sociedade. Rio de Janeiro: UERJ/PPGH. Retrieved from https://neip.info/novo/wp-content/uploads/2015/04/carva Iho_histria_poltica_criminalizao_drogas_brasil.pdf

Delamanto, J. (2015). Drogas e opinião pública no Brasil: hegemonia da desinformação. In V. Bokany (Ed.), Drogas no Brasil, entre a saúde e a justiça: proximidades e opiniões (pp.85-102). São Paulo: Editora Fundação Perseu Abramo.

Didi-Huberman, G. (2011). Coisa pública, coisa dos povos, coisa plural. In L. Nazaré \& R. Silva (Eds.), A República por Vir: Arte, Política e Pensamento para o Século XXI (pp.41-70). Lisboa: CalousteGulbenkian.

Didi-Huberman, G. (2015). O que vemos, o que nos olha. São Paulo: Editora 34.

Didi-Huberman, G. (2017). Diante da Imagem. São Paulo: Editora 34.

Fausto Neto, A. (2010). Enunciação midiática: das gramáticas às zonas de pregnâncias. In A. Fausto Neto, J. Ferreira, P. Gilberto Gomes \& J. L. Braga (Eds.), Midiatização e processos sociais: aspectos metodológicos (pp.27-38). Santa Cruz do Sul: EDUNISC.

Forin Junior, R., \& Boni, P. C. (2006). A globalização da exclusão social por meio da fotografia. Estudos em Jornalimo e Mídia, 3(1), 38-45. DOI: $10.5007 / \% 25 x$

Foucault, M. (1980). História da Sexualidade (vol.1): A vontade de saber. Rio de Janeiro: Graal.

Foucault, M. (2003). A vida dos homens infames. In M. B. da Motta (Org.), Ditos e Escritos IV, Estratégia, poder-saber (5ª. ed.) (pp.203222). Rio de Janeiro: Forense Universitária [1977].

Foucault, M. (2014). O sujeito e o poder. In M.B. da Mota (Org.), Ditos e escritos, v.9: genealogia da ética, subjetividade e sexualidade (pp.118-140). Rio de Janeiro: Forense Universitária.

Joly, M. (2007). Introdução à Análise da Imagem. Lisboa: Edições 70.

Machado, A. (1984). A ilusão especular. São Paulo: Brasiliense. 
Marin, L. (1998). Les Pouvoirs de L’Image. Paris: Seuil.

Martino, L. C. (2009). A Atualidade Mediática: o conceito e suas dimensões. Proceedings of the XVIII Encontro da Compós. Belo Horizonte, PUC-MG. Retrieved from www.compos.org.br/data/ biblioteca_1107.pdf

McCarthy, J.D., McPhail, C., \& Smith, J. (1996). Images of protest: dimensions of selection bias in media coverage of Washington Demonstrations, 1982 and 1991. American Sociological Review, 61(3), 478-499. DOI: 10.2307/2096360

Mallmann, I. F., Santos, A., \& Rosa, A. P. da. (2018). "Cuidado ao acessar. Imagens fortes": a circulação do discurso sobre violência urbana a partir de lógicas jornalísticas e policiais. Parágrafo, 6(2), 77-89. Retrieved from http://revistaseletronicas.fiamfaam.br/index. php/recicofi/article/view/827

Mondzain, M. J. (2009). A imagem pode matar? Lisboa: Vega.

Nancy, Jean-Luc. (2016). Demanda. Chapecó: Argos.

Oberling, A. F., \& Pinto, N. M. (2015). Reflexões sobre as representações da mídia no debate de drogas. In V. Bokany (Ed.), Drogas no Brasil, entre a saúde e a justiça: proximidades e opiniões (pp. 159-176). São Paulo: Editora Fundação Perseu Abramo.

Perlini, T. (2012). Le pacte moral comme condition d'existence du photojournalisme humanitaire. Cahier ReMix, 2(1), 1-15. Retrieve from http://oic.uqam.ca/en/remix/le-pacte-moral-comme-conditiondexistence-du-photojournalisme-humanitaire

Picado, B. (2009). A Ação e a Paixão que se Colhem num Rosto: pensando os regimes de discurso do retrato humano no fotojornalismo. Galáxia, (18), 276-290. Retrieved from https://revistas.pucsp.br/ galaxia/article/view/1898

Prass, M. A., \& Rosa, A. P. (2018). Ressignificação imagética: a narrativa da "muçulmana insensível" no atentado em Westminster. Conexão Comunicação e Cultura, 17(33), 223-238. DOI: 10.18226/21782687. v17.n33.10

Reis Filho, O. (2012). Reconfigurações do olhar: o háptico na cultura visual contemporânea. Visualidades, 10(2), 75-89. DOI: 10.5216/vis. v10i2.26551

Reis Filho, O. (2017). Imagens insurgentes: notas sobre a fotografia urbana no Ceará. Discursos fotográficos, 13(22), 107-127. DOI: 10.5433/1984-7939.2017v13n22p107

Reis Filho, O. (2019). O que pode a fotografia hoje? Notas sobre a 
experimentação e o lúdico nas obras de Rosângela Rennó e Alexandre Sequeira. In A. Marques \& F. Vieira (Eds.), Imagens e Alteridades (pp.96-109). Belo Horizonte: PPGCOM-UFMG.

Ronzani, T. M., Fernandes, A. G. B., Gebara, C. F. P., Oliveira, S. A., Scoralick, N. N., \& Lourenço, L. M. (2009). Mídia e drogas: análise documental da mídia escrita brasileira sobre o tema entre 1999 e 2003. Ciência e Saúde Coletiva, 14(5), 1751-1762. DOI: 10.1590/ S1413-81232009000500016

Rosa, A. P. (2016). Visibilidade em fluxo: os níveis de circulação e apropriação midiática da imagem. Interin, 21(2), 60-81. Retrieved from https://seer.utp.br/index.php/i/article/view/465

Rosa, A. P. (2017). Circulação: das múltiplas perspectivas de valor à valorização do visível. Proceedings of the VI Colóquio Semiótica das Mídias. Japaratinga, Alagoas: CISECO. Retrieved from www.ciseco. org.br/images/coloquio/csm6/CSM6_AnaPaulaRosa.pdf

Sá-Carvalho, C., \& Lissovsky, M. (2008). Fotografia e representação do sofrimento. Galáxia, 2(15), 77-90. Retrieved from https://revistas. pucsp.br/index.php/galaxia/article/view/1496

Sontag, S. (2003). Diante da dor dos outros. São Paulo: Companhia das Letras.

Sousa, J. P. (2004). Uma história crítica do fotojornalismo ocidental. Chapecó: Argos.

Stein, E. (2005). Sobre el concepto de empatia. Madrid: Trotta.

Stein, E. (2015). La estructura de la persona humana. Madrid: BAC.

Taylor, J. (2000). Problems in Photojournalism: realism, the nature of news and the humanitarian narrative. Journalism Studies, 1(1), 129143. DOI: $10.1080 / 146167000361212$

Wurdig, K. K., \& Motta, R. F. (2014). Representações Midiáticas da Internação Compulsória de Usuários de Drogas. Temas em Psicologia, 22(2), 433-444. DOI: 10.9788/TP2014.2-13

Zumthor, P. (2018). Performance, recepção, leitura. São Paulo: Ubu.

Zerwes, E. (2017). A fotografia humanista e a construção de uma historiografia sobre a fotografia latino-americana. Revista História: Debatese Tendências, 16(1), 314-317. DOI: 10.5335/hdtv.16n.2.6920 
LUÍS MAURO SÁ MARTINO. Professor of the Graduate Program in Communication at Faculdade Cásper Líbero and researcher at Faculdade Cásper Líbero, SP. PhD in Social Sciences from PUC-SP. He was a research fellow at the University of East Anglia, England and is the author of the books Métodos de Pesquisa em Comunicação (Vozes, 2018), Teoria da Comunicação (Vozes, 2009), Comunicação e Identidade (2010), and The Mediatization of Religion, published by British publisher Routledge in 2016. He published, in coauthorship with Ângela Marques, the book Ética, Mídia e Comunicação (Summus, 2018). E-mail address: Imsamartino@gmail.com

Collaboration in the article: development of theoretical discussion and analysis, support in text review.

VITÓRIA PRIETO AMÁ. Graduated in Journalism at Faculdade Cásper Líbero (2018). She received a Scientific Initiation scholarship from the Interdisciplinary Research Center at Faculdade Cásper Líbero (CIP). She is a researcher at the Research Group "Theories and Processes of Communication" of the Graduate Program in Communication at Faculdade Cásper Líbero. E-mail address: vitoriapama@gmail.com Collaboration in the article: collection of empirical data, development of theoretical discussion and analysis, support in text review.

ÂNGELA C. S. MARQUES. Professor of the Graduate Program in Communication at UFMG. $\mathrm{PhD}$ in Social Communication from UFMG. She is a CNPq researcher and has a postdoctoral degree from Stendhal University, Grenoble III, in France. She is the author of the books Apelos solidários (Intermeios, 2017), written with Angie Biondi; Diálogos e Dissidências: M. Foucault e J. Rancière 
(Appris, 2018), with Marco Aurélio Prado; and Ética, Mídia e Comunicação (Summus, 2018 ), with Luis Mauro Sá Martino. She is the coordinator of the book Vulnerabilidades, justiça e resistências nas interações comunicativas (SELO PPGCOM, 2018). E-mail address: angelasalgueiro@gmail. com

Collaboration in the article: development of theoretical discussion and analysis, support in text review.

\section{TRANSLATED BY: JOÃO ANACLETO}

One review used in the evaluation of this article can be accessed at: https://osf.io/cvz7f | Following BJR's open science policy, the reviewers authorized this publication and the disclosure of his/her names. 